\title{
Celestina's Influence on La casa de Bernarda Alba
}

\author{
Luis F. López González
}

Accepted: 2 January 2021 / Published online: 2 February 2021

(C) The Author(s) 2021

\begin{abstract}
This study argues that the breadth and depth of influence of Fernando de Rojas's Celestina on Federico García Lorca's La casa de Bernarda Alba is much greater than previously acknowledged. García Lorca borrowed from Rojas not only motifs, images, and characterization, but also symbols, structure, and the effusive rhetoric that characterizes Celestina and Melibea's mode of expression. Lorca's La casa contains a microcosm of the social institutions and cultural dynamics that predominate in Celestina's world and, by extension, in Rojas's society. In this comparative analysis, I hope to show the far-reaching influence that Celestina has had since its publication in 1499 up to the twentieth century. By reading Lorca's play from this perspective, I also uncover new levels of meaning that help us interpret La casa based on the systems of intertextual relations that underprop La casa's foundations.
\end{abstract}

Keywords Celestina · Bernarda Alba · Melibea · Adela · Desire · Characterization · Influence

The craft of reading cognitively correlates with the art of writing. Joseph T. Snow states that when writing, any author may be reflecting, at least in part, the sum of his experiences and of his history of readings. Consciously or unconsciously, he notes, authors recast some of their reading experiences into even the most original work: "The material is later absorbed and modified in its new environment" $(2008,81)$. Snow's insightful opinion is undoubtedly true of Federico García Lorca whose most celebrated play, La casa de Bernarda Alba (1936), is deeply indebted to Fernando de Rojas's Celestina (1499). Largely because Lorca aims at reproducing "un documental fotográfico" $(2011,138),{ }^{1}$ a realistic feature it shares with Celestina, La casa contains not a single mention of an author or work. The hovering presence of Celestina in Lorca's drama, however, is too extensive to ignore.

\footnotetext{
1 I quote from Vilches de Frutos's edition. From now on, I offer the page number in the text.
}

Luis F. López González

lf.lopez@vanderbilt.edu

1 Vanderbilt University, Nashville, USA 
Thanks to Christian de Paepe and Manuel Fernández-Montesinos García's archival work on Lorca's personal library, we know that Lorca owned the 1932 EspasaCalpe edition of Rojas's Celestina. The physical description of Lorca's copy by De Paepe and Fernández-Montesinos García suggests that Lorca studied Rojas's work scrupulously. Lorca's copy of the book lacks the back cover-itself a sign of useand it contains "anotaciones y pasajes destacados y subrayados a lápiz negro y rojo y a plumilla en tinta negra" $(2008,118)$. Lorca's intellectual engagement with this work can be discerned not only through his written annotations in the margins, but also by the different colors used to highlight and underline certain sections of Celestina, which indicates that he planned to return to those scenes later.

The connection between Celestina and La casa has been obliquely suggested by both Rojas and Lorca scholarship (Sears 1992, 94; Klein 1991, 3). Eduardo Galán Font, though, is the only critic who has taken on the task of pointing out some obvious similarities between both dramas; most prominently, he observes, the affair of Calisto and Melibea lies behind that of Pepe el Romano and Adela, and similar social conditions pave the way for the women's suicides. In a recent paper, María Valeria Mancha (2019) explores the dramatic effects of unattainable love in relation to Melibea and Adela, focusing on the patriarchal oppression that provokes their suicides.

These two articles have uncovered but the surface of Lorca's debt to Celestina. In my study, I hope to show that Lorca's literary borrowings are deeper than the references and motifs suggested by Galán Font and Mancha. The intertextuality can be observed not only in the edifice of La casa, but also in the dramatic thrust of Bernarda, Adela, and Poncia's characterization, which recalls that of Celestina and Melibea. Lorca is deservedly renowned for his poetic genius, a gifted artist who possessed a heightened sense of aesthetic sensibility and a clear consciousness of his literary craft, but he was also an avid and discerning reader. During a 1935 interview, the poet was asked if he read a lot, to which he replied: "Tuve épocas de leerme dos libros diarios" (Del Río 1972, 283). Lorca was steeped in Renaissance, Golden Age, and modern as well as Elizabethan literature, as is suggested by the great breadth of authors and books that made up his personal library. ${ }^{2}$ Celestina, whose historical influence, cultural value and relevance in Spanish literature is incontestable, looms large among Lorca's readings. This opinion is supported by Lorca's Celestinesque renewal of motifs, symbols, imagery, representation of public and private spaces, social structure, dialogue, and characterization. Some borrowings, of course, are more unmistakable than others, which begs the question: Were his loans conscious or unconscious? The reality is that we do not have a direct answer to this query. Instead, Lorca's text speaks for itself, and it reveals that the Andalusian poet had a profound understanding of Rojas's drama.

\footnotetext{
${ }^{2}$ For Lorca's indebtedness to Shakespeare's theater, see Andrew A. Anderson (1985).
} 


\section{Celestina and La casa de Bernarda Alba}

What came to be known as Celestina was published by Fernando de Rojas in 1499 with the title Comedia de Calisto y Melibea. It contained sixteen acts with introductory paratexts. Rojas explains in a caustic preface to the 1502 Seville edition that he was importuned by his readers to expand the work. To please his audience, he added five more acts, and printed the complete work with a slightly different title: Tragicomedia de Calisto y Melibea. Later editors titled it Celestina for the procuress who has a larger-than-life presence in the storyline. Since the outline of this evolution is included in every old and modern edition of Celestina, Lorca certainly was aware of it. Lorca's first dramatic piece Tragicomedia de don Cristóbal y la señá Rosita (1922), a guiñol that contains the same social criticism and motifs of unattainable love that undergird his three tragedies-Bodas de sangre, Yerma, and La casa-as well as the historical play Mariana Pineda, pays homage to Celestina. "Tragicomedia" is a label as firmly attached to Rojas's masterpiece as is the title character's name, which has been made into a verb in contemporary Spanish.

The similarities become more remarkable in the actual contexture of La casa. The ages of multiple characters from both works are the same. In his mournful planctus (plaint), Pleberio apostrophizes Melibea's body, lamenting the dissonance of life: "Más dignos eran mis sesenta años de la sepultura que tus veynte" (2001, 608). ${ }^{3}$ Adela is also 20 years old. When Magdalena censures the impending wedding of Pepe el Romano with Angustias, who is 40, she believes that Pepe should marry Adela instead because she "tiene veinte años" (177). Bernarda, like Pleberio, is 60 years old. Her age only appears in the cast of dramatis personae: "Bernarda, 60 años." Rojas borrowed the sixty-twenty idea from Diego de San Pedro's Cárcel de Amor (1492). Leriano's mother reflects upon the world-upside-down theme beside her son's deathbed: "Más razón havía para que conservases los veinte años del hijo moço que para que dexases los sesenta de la vieja madre" (1971, 173-74). The symmetry between their ages could have been derived from San Pedro's work, but more likely was derived from Rojas's work. Poncia and Celestina, who was a prostitute just like Poncia's mother, are also the same age. Although Pármeno estimates that Celestina is 72 years old ("sus seys dozenas de años a cuestas" 293), the go-between claims otherwise, referring to herself as "una vieja de sesenta años" (497). In light of Pármeno's appraisal, Peter E. Russell wonders if Celestina's statement represents mere "vanidad" (2001, 497). For my part, I see no reason to doubt Celestina's assertion, which is expressed in earnest during a moment of high tension and existential threat. A similar discrepancy can be observed in La casa, not with regard to Poncia's, but Angustias's age. ${ }^{4}$ Lorca lists Poncia in the dramatis personae as a 60-year-old servant. Lorca breaks with Rojas regarding Pepe's age, but not by

\footnotetext{
${ }^{3}$ I quote from Russell's edition. From now on, I offer the page number in the text.

${ }^{4}$ When Poncia asks Bernarda for Angustias's age, the latter says that she is 39 (125), but Magdalena later says that Angustias is 40. Lorca, just as Rojas had with Celestina's age, never reconciles these two contradictory statements.
} 
much. During her first visit to Pleberio's house, Celestina tells Melibea that Calisto is 23 years old (336). Pepe, if Magdalena is correct, is 25 (176).

Melibea and Adela, both of whom are reportedly unattractive, ${ }^{5}$ are ailed by the same condition: lovesickness. They also exhibit comparable physiological manifestations. Although Galán Font compares Adela's sickness with Calisto's, the similitudes between Adela's and Melibea's ailments are far more striking. The first word of Melibea's lovesickness comes during the banquet scene of act IX when Lucrecia, whom Melibea has sent to call upon Celestina to treat her sudden affliction, avers that Melibea feels "muy fatigada de desmayos y dolor del coraçón" (436). As soon as Celestina crosses the threshold, Melibea reveals her lovesickness, invoking the imagery of the serpent in her chest eating her heart alive: "Madre mía, que me comen este coraçón serpientes dentro de mi cuerpo" (441). The metaphorical use of the serpents here is meant to evoke the serpentine oil that Celestina employed in her love spell (“ $; O$ serpentino azeyte!” 342). ${ }^{6}$ Lorca takes full advantage of this suggestive image by making Poncia describe Adela's lovesickness: "La encuentro sin sosiego, temblona, asustada, como si tuviera una lagartija entre los pechos" (190). In an even more direct fashion, Adela paraphrases Melibea's words, expressing her desire to escape her confinement in order to allay "lo que nos muerde" (213), in reference to Melibea's figurative biting serpents. Although Calisto had also claimed to have felt "dentro del pecho aguijones" (233), Lorca's expressions were likely inspired by Melibea's words. Adela's illness is evident to and commented upon by nearly everyone in the house. Poncia, who, just as Celestina does within her own society, knows everything about everyone in the house, states: "Esa niña está mala" (199). Angustias adds that her eyes are starting to look like those of a crazy person. When Adela enters the scene, she confirms her malady: "Tengo mal de cuerpo" (200), a syntax reminiscent of Areúsa's phrase "mal de la madre," uttered at the outset of act VIII. Adela's symptoms, however, mirror those of Melibea. As seen above, Poncia finds the following signs in Adela: restlessness ("sin sosiego"), trembling ("temblona”), and fear ("asustada”), while Martirio notes her sleeplessness: "¡No duerme apenas!" (199). Like Poncia, Lucrecia perceives Melibea's "poco sossiego" (restlessness), "meneo de tus miembros" (trembling) change of facial hue, fear, and sleeplessness (453). The connections are patent even in the use of language. But the overarching condition that likens the two protagonists is their acute case of lovesickness, a psychoaffective illness that controls their emotions and sensory perception.

Melibea and Adela's irrepressible passion leads them to reject the stringent social norms that repress basic women's rights and police female sexuality. Their desires, metaphorically represented as serpents and lizards, are eating them alive. Both

\footnotetext{
5 See Elicia's and Areúsa's rather unsavory descriptions of Melibea during the banquet scene in act IX (421). Even Calisto, who describes Melibea in act I as a type of the pulchra puella, acknowledges that other ladies are comelier than Melibea (355). In the opening scene of act I, Poncia has some colorful words to describe Bernarda's daughters: "Le quedan cinco mujeres, cinco hijas feas" (144).

6 The use of magic and its effects is and has been one of the most outstanding points of contention in Celestina scholarship. For my part, I believe, with Russell, Severin, and those who defend the efficacy of the hilado, that Rojas makes a great effort to show the connection between Melibea's lovesickness and Celestina's spell cast in act IV.
} 
heroines disavow their parents, ironically, not on the altar of personal freedom or individuality. Instead, Melibea and Adela merely seek a shift of allegiance. They yearn to submit their bodies, their wills, and their lives to their lovers. In act XVI, Pleberio and Alisa reflect upon the transience of life, noting that their own lives are coming to an end, which leads them to think about making arrangements for Melibea's marriage. Upon hearing her parents' misguided thoughts, Melibea concedes that she is utterly subjected to Calisto's will: "Haga y ordene de mí a su voluntad" (547), thus actualizing Celestina's prophetic words of act XI. ${ }^{7}$ In Lorca's drama, Adela recasts the same sentiment: "Seré lo que [Pepe] quiera que sea" (272). Confronted with the possibility of renouncing her lover, Adela affirms her subjectivity, womanhood, and sexuality: “¡Mi cuerpo será de quien yo quiera!” (202), a subversive cry that really means "my body belongs to Pepe." This interpretation is later confirmed when she breaks Bernarda's cane and, overtaken by anger, screams: “En mí no manda nadie más que Pepe!" (275). The verbs "ordenar" (Melibea) and "mandar" (Adela) suggest intertextuality, as well as a breakdown of the girls' sense of self. Melibea pushes the limits even further: "Si [Calisto] passar quiere la mar, con él yré; si rodear el mundo lléveme consigo; si venderme en tierra de enemigos, no rehuyré su querer" (547). Both Melibea and Adela consider themselves mere objects of their lovers' whim.

Echoing his ballad "La casada infiel" from Romancero gitano and Bodas de sangre, Adela states that Pepe takes her to the juncos (reeds) of the river ("orilla"), imagery that recalls María Josefa's longing to marry a handsome man at the seashore. Adela, subsequently, expresses a desire to flee with her lover, albeit tamping down the melodramatic tone that has arched over the entire interaction with Martirio: "Yo me iré a una casita sola donde él me verá cuando quiera" (272-73). The notion of escaping to a distant place with their lovers is clearly articulated through similar wording (Melibea: "Con él iré"; Adela: "Yo me iré"). Because of their inability to marry the men they love, Melibea and Adela reject marriage unequivocally, invoking the malcasada or malmaridada leitmotif. While eavesdropping on Pleberio and Alisa's plan to marry her, Melibea tells Lucrecia: "Más vale ser buena amiga que mala casada" (547), then adding "no quiero marido, no quiero ensuciar los ñudos del matrimonio." She ends by disavowing her parents and, by extension, all the social mores that her parents advocate and incarnate: "iQue ni quiero marido, ni quiero padre ni parientes!" (551). The same response can be discerned in Adela. She tells Martirio, who is also sick with love for Pepe, that she would rather face social ostracism and physical pain than accepting-like all the female protagonists of Lorquian tragedies, as well as the Tragicomedia de don Cristóbal-a marriage of convenience: "Me pondré delante de todos la corona de espinas que tienen las que son queridas de algún hombre casado" (272). Beyond the Christological undertones, Adela claims to be not only willing but even eager to endure the fate and suffering of those who, like Librada's daughter or even Novia from Bodas de sangre, succumb to the urges of the flesh out of wedlock. Her explicit rejection of family

\footnotetext{
7 Celestina: “[Melibea] es más tuya que de sí misma, más está a tu mandado y querer que de su padre Pleberio" (460).
} 
expectations and social values is on full display when she stops Bernarda's authority in its tracks by breaking her cane and interjecting: “ ¡Aquí se acabaron las voces de presidio!" (275). At this juncture, Adela is determined to escape the house and her mother's domination at any cost. She is so alienated by her lovesickness that the aberrant nature of her desire for her sister's betrothed is a nonfactor in her decision to elope with Pepe. Melibea's dramatic expression "no quiero padres ni parientes" becomes Adela's worldview. Lorca renews and beautifies Melibea's principle by making Adela defend her feelings: "Nos enseñan a querer a las hermanas. Dios me ha debido dejar sola, en medio de la oscuridad, porque te veo como si no te hubiera visto nunca" (274). Adela's repudiation of family bonds is reminiscent of Melibea's, but the most salient feature that unites both characters is their effusive rhetoric with which they communicate with others throughout the dramas, a saliency that renders both women dramatically forceful and tragically memorable.

The consensus in Lorca scholarship is that La casa was built on the pillars of the themes of love, death, and honor, ${ }^{8}$ all of which are fatefully interconnected. These same premises are at work in Celestina; they not only sustain the plot, but also push the narrative to its tragic end. In both works, love evolves into an all-consuming desire, a physical condition that Ricardo Castells calls "grotesque realism," a type of human behavior that revolves around the materiality of the body, rather than of higher ideals. Assisted by Mikhail Bakhtin's theory of the body and the grotesque, Castells describes "grotesque realism" as a rejection of ingrained social values in favor of immediate gratification. He argues that "Calisto makes the transition from the ethereal Melibea to the physical presentation of Melibea when he describes the young woman in descending order as a collection of cabello, ojos, pestañas, nariz, dientes, and tetas" (1992, 15). After fulfilling his desire, Calisto perceives Melibea as a sexed object, nothing more. Indeed, Calisto later equates Melibea to a dainty bird that he has to pluck (unclothe) before consumption ("señora, el que quiere comer el ave, quita primero las plumas" 584). Pepe, who is set to marry Angustias, also treats Adela as mere delicacy, a savory dish to appease his appetite before his wedding. Melibea and Adela suffer a similar degradation. Both of them are raised cosseted by affluent families, expected to reach their families and society's most sacred ideals - a traditional marriage, a family, and a devout life. They are raised to become mirror images of their mothers. Instead, they abandon their upbringings to pursue their intense desires. This "grotesque realism" fuels their transgression and rebellion, dishonors their families, and results in death. As Miguel A. Martínez's briefly, yet eloquently, puts it, "Adela se rebela, lucha y muere" (1970, 64). Although attenuated by Pleberio's less stern authority, the same holds true for Melibea.

Rojas also inspired Lorca in Bernarda's characterization. Pleberio and Bernarda have more features in common than their age. They blur and often efface the line that divides gender roles. Stephen M. Hart has seen masculine features in Bernarda's

\footnotetext{
8 "Bernarda Alba and her five daughters are immersed in a violent affair involving love, death, and honor" (Sharp 1961, 230), later echoed by Richards: "The tragedies center around the familiar Spanish preoccupation with love, death, and honor-themes which bring into play individual feeling, universal necessity, and the norms that characterize a particular society" $(1983,215)$.
} 
characterization, going as far as calling her "mujer varonil" (1989, 65). In act VII, it is Celestina who describes Claudina, Pármeno's mother, as "mujer varonil," in both cases without the positive connotations with which the term was usually employed in the Middle Ages (Swietlicki 1985). Hart opines that Bernarda "has fully internalized the phallocentric system of masculine dominance, using it for her own ends" $(1989,66)$. After the death of her second husband, she adopts the roles of father and mother; she has to tend to her lands and horse-breeding trade, while also educating (subjugating) her daughters and managing her household. Prudencia comments upon Bernarda's gender ambiguity: "Bregando como un hombre" (245). Bernarda, just as Pleberio does, derives her power from the possession and exploitation of the land, an outmoded form of the pre-modern (and pre-Rojas) feudalism that Isaac Rubio terms "sociedad semifeudal" (1980, 172). A similar blurring of gender lines can be observed in Pleberio's characterization. His planctus (literally "weeping"), which is modelled after that of Leriano's mother in Cárcel, helps to portray him as an effete and feminine figure. His crying, whining, and helplessness, behaviors generally attributed to women in the Middle Ages, are a far cry from the dominant medieval male figures of, inter alia, El Cid, El Marqués de Santillana, and Jorge Manrique who adopt a stoic outlook when facing loss. In keeping with the courtly love aesthetics, a genre that informs not only Pleberio's discourse but also his worldview, his weak and womanly plaint portrays an overtaken man, ill-suited to face the vicissitudes of life. As such, the final lament would be more proper for his wife Alisa.

Pleberio and Bernarda are not only self-delusional regarding their daughters' innocence and obedience. They also err in not marrying their daughters in a timely manner, a parental oversight that has puzzled generations of Celestina scholars. Pleberio and Alisa only consider betrothing Melibea after they believe that death is upon them and feel the need to fulfill the moral obligation of arranging their worldly affairs before departing to the next life. An analogous dereliction is highlighted by Poncia in La casa. The servant reminds Bernarda of her refusal to accept Enrique Humanes as Martirio's fiancé, an accusation that the matriarch dismisses hubristically by pointing out Enrique's humble origins. After the death of Antonio María Benavídez, the daughters' hope of finding suitable husbands is bleaker since Bernarda has vowed to lock them in for eight years, in addition to the fact that she is convinced that her social position is above that of any other man in town. Just as Bernarda treats her daughters as symbolic capital or commodity with whom to increase her own honor and wealth, Pleberio too has subjected Melibea to what Julio Rodríguez Puértolas calls "un amor ya cosificado y mediatizado por los más típicos 'valores' de la burguesía" (2007, 30), adding, "Pleberio, una figura patética, sin duda, no es inocente. La cosificación a que ha sometido a su hija así lo demuestra" (2007, 31). Theresa Ann Sears notes in Pleberio's lament a selfish preoccupation with his own suffering, rather than with his daughter's death $(1992,102)$. The same can be said about Bernarda's stone-cold egotism and disregard for her daughter's suicide. Pleberio and Bernarda behave selfishly and constantly put their self-interest above their daughters' wellbeing. The last parallel worth pointing out between Pleberio and Bernarda is the identical position they hold within the family structure, society, and the storyline as heads of their households. They are representatives of 
the business class, tasked with the onerous responsibility of maintaining the families' honra.

The notion of honra is, to be sure, an abstract and an undefinable cultural ideal as well as a shared experience and an axiological construct. As such, honra is an intrinsic part of Hispano-Roman ontology (see Aguilar Piñal 1986). Properly speaking, therefore, it cannot be said to belong to a particular author or milieu. The premium that premodern, modern, and even postmodern Spaniards placed on this concept is well known, making it difficult to assign influence of one author over another. Yet we would do a disservice both to Rojas and Lorca if we were to ignore the parallels that stem from its application in the plots. The first element to notice is the correlation between (des)honra and death, which is already on full display in King Alfonso X's Siete Partidas (ca. 1252-84). Julio Caro Baroja has studied the implications of honra in medieval society, culture, and literature, noting that in Alfonsine legislation: "La pérdida de la honra se equiparaba a la pérdida de la vida" $(1964,414)$. This assertion holds tragically true for Celestina and La casa. Caro Baroja offers a striking diagram that further illustrates the prominence that medieval societies placed on this system of values:

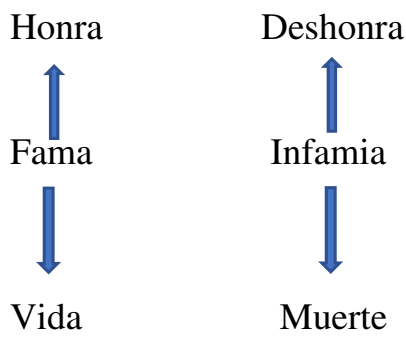

This paradigm lays bare the teleology of an ill reputation, which causes dishonor and death. Conversely, a good standing leads to honorability and life. The notion of "fama" (repute) as the springhead of life is unequivocally affirmed in Jorge Manrique's celebrated "Coplas a la muerte de su padre" (1477). This elemental ideal is no mere literary conceit. It was an essential part of human relations and a core tenet of social institutions.

Rojas and Lorca not only understood these imperatives. They recognized the seed for tragedy hidden beneath. They knew that their societies valued people not in proportion with personal virtue or moral integrity, but with appearances and public opinion. Guided by this sociological awareness, they sought to make their characters reflect upon and live through these idiosyncrasies that rewarded repute with honor and life, and punished dishonor with exclusion and death.

Melibea consistently equates her loss of honra to the loss of her life. In act X, she claims to prefer death over losing her good name. When Celestina insinuates her illicit union with Calisto, Melibea complains: "Más agradable me sería que rasgases mis carnes y sacasses mi coraçón" (448-49). After the death of Pármeno and Sempronio at the hands of the police, Calisto likewise favors death over dishonor: "Pluguiera a Dios que fuera yo ellos y perdiera la vida y no la honrra" (506-07). Lorca 
actualizes this ideal through the deaths of Adela and Librada's daughter, who had a premarital affair, gave birth, and killed the baby. Upon hearing the uproar of the crowd stoning the hapless girl, Bernarda calls for her expeditious lynching, evoking, as Ann Bugliani observes, the Biblical story of Mary Magdalene (2001, 84). Bernarda stresses the punitive function of society, which operates to repress human desire, screaming from inside the house: "Que vengan todos para matarla" and then "que pague la que pisotea su decencia" (239). Looking at Adela, Martirio echoes her mother's draconian expression: “iQue pague la que debe!” (240). Martirio's fury is not directed against Librada's daughter, but against Adela. Bernarda, who is still unaware of Adela's transgression, urges a swift murder: " $i$ Acabar con ella antes que lleguen los guardias! ¡Carbón ardiendo en el sitio de su pecado!” (240). Medieval scholars will discern a direct reference to the legend of María Coronel in Bernarda's last exclamation. María Coronel, as recounted in Juan de Mena's Laberinto de Fortuna (1444), San Pedro's Cárcel, and others, allegedly mutilated her genitals with hot coals in order to quell her burning lust when her husband was at a military campaign against the Andalusian Moors. Francisco Sánchez de las Brozas (1523-1600) uses terminology and syntax to describe María Coronel's effacement that recall Lorca’s ("metióse un tizón ardiendo por su natura" Cummins 1990, 92). Bernarda's hysterical screams “¡Matadla! ¡Matadla!” convey her intransigent sense of morality and her vindictiveness. Her visceral reaction is informed by the fact that she appraises her sense of morality and subjectivity by contrast of libertine women, such as this wretched girl, Paca la Roseta, and Poncia's mother. For Bernarda, only lowborn women can express and exercise their sexuality: “¡Ésa es la cama de las malnacidas!" (275), a distinction also articulated by Celestina to explicate Melibea's initial rejection in act IV: "Si assí no fuesse, ninguna diferencia havría entre las públicas que aman, a las escondidas donzellas" (353).

Gossip, a cultural phenomenon associated with honor and reputation, contributes to the tragic end in Rojas's and Lorca's dramas. Magdalena verbalizes the anxiety caused by the fear of slander: "Nos pudrimos por el qué dirán" (172). "El qué dirán" can be broadly defined as a type of malicious gossip, aimed at defaming and harming others. Bernarda's decision to confine her family inside the house is only tangentially informed by the mourning of her late husband. She isolates her daughters (and her mother) to protect them from defamation. Dennis A. Klein is correct in noting that Bernarda simultaneously controls others and is controlled by the fear of "quedirán" (1991, 67). Amelia blames this culture of toxic discourse for her and her sisters' woes: "De todo tiene la culpa esta crítica que no nos deja vivir" (168). Bernarda does not allow her mother outside of her room-cell because she is afraid people will see her and turn her into fodder for gossip. When María Josefa escapes from her chamber, Bernarda asks the Criada to move her away from the well. The servant misconstrues Bernarda's motives, reassuring her "no tengas miedo que se tire" to which Bernarda retorts: "No es por eso. Pero desde aquel sitio las vecinas pueden verla desde su ventana" (160). Even Poncia, who is likely the product of prostitution, lives in fear of being sullied by ignominy. She makes it abundantly clear that she does not care about the intramural brawls and the ensuing suffering that plague a family riven by envy and hate. She only mediates disputes because "quiero vivir en casa decente. ¡No quiero mancharme de vieja!” (206). Mostly for selfish reasons, 
Bernarda takes this social axiology to the extreme. She knows that a stain on her daughters' good name besmirches everyone within the household. C. Brian Morris reminds us that Bernarda perceives her daughter's isolation as an ideal way of life and dismisses other modes of existence because they threaten her own social standing (1986, 131). Lorca represents "el qué dirán" as a weapon, wielded to hurt others, as showcased in Mujer 3. a's sotto voce insult to Bernarda: “¿Lengua de cuchillo!" (151).

The emphasis on malicious gossip is also a source of anxiety for all characters in Celestina, from Pleberio and Melibea to Celestina and Areúsa. Fear of el qué dirán conditions not only the way they interact with each other, but also the way they perceive themselves and the world. In act X during Calisto's first visit, Melibea complains about being unable to see him from behind the door. Calisto, whose cowardice is on full display throughout the drama, offers to knock it down. Melibea dissuades him, adducing her reputation: "Por que mi honrra y persona estén sin detrimento de mala sospecha seguras," and "no quieras poner mi fama en la balança de las lenguas maldezientes" (476). Should their secret be revealed, both Calisto and Melibea risk dishonor and even death. Just before Calisto's departure from her door, Melibea begs him to reward his servants handsomely so that "en todo te guarden secreto" (486). Melibea is not the only one who understands the threat of gossip. Even Celestina, whose concern for her reputation mirrors Poncia's, wields elqué dirán to defend herself from Pármeno and Sempronio's aggression. Just before her death, Celestina threatens the irate servants with spreading the secret if they do not abate their abuse: "No queráys que salgan a plaza las cosas de Calisto y vuestras" (498). After Celestina's death and the murderers' ensuing execution, Calisto laments, not their deaths but, the spillage of his secret into the public domain: “ $E n$ que anda mi hazienda de mano en mano y mi nombre de lengua en lengua!" (507). In the vortex of his desolation, Pleberio takes solace in the fact that Melibea's death removes his fear of losing his honra on account of his daughter's actions. ${ }^{9}$ Public gossip is not only triggered by actual acts of transgression. Appearance and malice also spread harmful rumors. The sense of anxiety caused by the dread of being exposed to dishonor that distresses all characters in Celestina as well as in Lorca's tragic trilogy is overwhelmingly rooted in public opinion. Melibea, Calisto, Bernarda, and even Poncia and Celestina, place a higher premium on appearances than on actual acts of immorality. This helps explain why at the end of the play, Bernarda is more concerned with covering up Adela's affair than with losing her daughter. She lets her fear of qué dirán supersede any telltale of motherly love, a stoniness that stands in stark contrast to Pleberio's openness and candor after Melibea's suicide.

Luis Fernández Cifuentes has interpreted the spatial economy of Lorca's La casa in terms of borders that divide territory and people. The interior of the house, he posits, is rendered into a "territorio conflictivo que es a la vez abierto y cerrado, que reúne y dispersa, reprime y libera” $(1986,192)$. Spaces are divided and defined

\footnotetext{
9 "Agora perderé contigo, mi desdichada hija, los miedos e temores que cada día me espauorecían: sola tu muerte es la que a mí me haze seguro de sospecha" (614). Ironically, Melibea's loss of chastity and suicide have caused irreparable damage to Pleberio's reputation.
} 
according to gender and social roles. In Rojas's book, affluent maidens stay inside the house to avoid unwelcomed gossip, while men and prostitutes are free to roam around the streets less encumbered by people's opinion. In medieval medical lore, isolation and idleness were considered adverse both for the body and mind. Seclusion was believed to augment the melancholic humor, thus creating a humoral imbalance that resulted in depressive states, bursts of anger, madness, and suicidal impulses. $^{10}$ To this effect, Bugliani poses a chicken-and-egg paradox: Is María Josefa insane because she is confined or is she confined because she is insane? (2001, 85). It is thought provoking, and we will do well to recall that Adela was already acquiring the look of a madwoman. These psychosomatic effects stress the relevance of space in La casa and Celestina. Whereas Rojas represents the separation of female and male spaces without apparent judgment, Lorca portrays the exclusion of young ladies from social and political life as criticism levelled against ultraconservative mores. Bernarda defines the boundaries with an evocative metaphor: "Hilo y aguja para las hembras. Látigo y mula para el varón" (158). In Bodas de sangre, Madre, who expresses serious apprehensions regarding Novia's chastity and reputation, voices her own opinions apropos gendering spaces: “¡Los varones son del viento! [...] Las niñas no salen jamás a la calle" $(1995,132)$. This spatial dichotomy takes on more misogynistic undertones in Yerma, both because it is uttered by a man (Juan, Yerma's husband) and because he equates women to animals: "The sheep in the pens, and the women in their houses" (1993, 150). Bernarda adopts this attitude as dogma, knowing full well that her social position depends largely on never violating the boundaries that separate men from women and bien nacidas from "mal nacidas."

The houses are paramount in the economy of the drama because either all ( $\mathrm{La}$ casa) or most (Celestina) of the action takes place inside these spaces. The architectural spaces of Pleberio's and Bernarda's houses are virtually the same. Rojas describes Pleberio's house as an urban mansion with the tower from which Melibea jumps to her death, comprised of an interior space and an exterior garden. Bernarda's house is a large Andalusian residence with a spacious interior and the corral. The houses have other areas, such as Melibea's chamber or Bernarda's sewing room, but they play no significant role in the unfolding of the narratives. The dramatic use of space is akin in both works. The interiors are mostly domestic precincts where intimate matters are revealed and discussed, a war zone ("Poncia: [...] casa de guerra" 261) in Bernarda's house. Save for Pleberio, both houses are entirely inhabited by women. Men are generally barred from entering into these walled-in zones, and unmarried women, except for servants, do not (or cannot) leave the premises of the property. As noted above, Bernarda has forbidden her daughters to leave the house until the eight-year period of mourning elapses, a tradition she had to abide by when her own father died. Rojas constantly describes Melibea as a "encerrada donzella" (440, 451), and she never appears outside her home. In a comment that derives from a rather slanderous invective, Areúsa confirms Melibea's reclusion, stating that Melibea "todo el año se está encerrada" (421). The irony here is rather

\footnotetext{
${ }^{10}$ See my forthcoming article, "The Melancholic Complexion of Melibea." Modern Language Review.
} 
obvious. The noble lady hides from public view to preclude gossip, and Areúsa turns Melibea's preventive measure into slander, suggesting that she hides in order to conceal what Areúsa describes as vomit-provoking ugliness (421). The external spaces, likewise, serve the same purpose in the narratives. They are the loci in which the lovers conduct their affairs. Calisto and Pepe climb over the walls into the private area after midnight, satiate their desire, and depart just before dawn. Calisto, Melibea, Adela, and (at least in Adela's mind) Pepe die right after their last amorous encounter and, one may surmise, around the same hour, just as the people of their towns are waking up to start the day.

The plotline unfolds in mid-summer in both works. In Celestina, it can be deduced from context, but Russell makes sure to point this out for readers: "La acción de la obra debe situarse en pleno verano" (2001, 517). In La casa, the stage direction indicates the season: "Es verano" (139), and Martirio is desperately awaiting the cooler month of November because she is sick of "este verano interminable" (215). The season, in turn, serves as a scaffolding platform on which to set the unfolding of the play. Martínez fittingly connects the summer heat to the simmering tension building in Bernarda's house and the sociopolitical ferment playing out at the dawn of the Spanish Civil War, the time in which Lorca is composing the drama $(1970,62)$. But the summer heat has other dramatic functions in the development of scenes, which help add verisimilitude to Celestina and La casa. Because of the warm weather of summer, the lovers can meet at or after midnight without the discomfort of the cold rain that Martirio so desperately craves. Indeed, Rojas and Lorca employ the hour of midnight as a trope. The fateful night of their demise, Melibea echoes the lyrical expression of Romancero aesthetics, lamenting Calisto's tardiness: "La media noche es passada, y no viene" (581). Lorca also stages Adela and Pepe's trysts around the midnight theme. Angustias tells her mother that Pepe departs from her window at one in the morning (234), even as she later says that he left one time at twelve-thirty (250). In the scene of Pepe's stolen picture, Martirio, who has taken the photo because she, just as Calisto does with Melibea's sash (Weinberg 1971, 145), equates it to Pepe’s body, maliciously wonders: “¿Y no se habrá escapado a medianoche al corral? A Pepe le gusta andar con la luna” (219).

The allusion to the summer season further allows Rojas and Lorca to justify their female protagonists' act of getting out of bed at midnight to receive their lovers. Since it is hot, Melibea and Adela can excuse their presence at unbecoming hours by claiming to be thirsty. When Pleberio hears noises outside Melibea's chamber just after Calisto departs in act X, the father apprehensively calls upon his daughter, prompting Melibea to mislead him: "Señor, Lucrecia es, que salió por un jarro de agua para mí, que había gran sed" (487). Even though he lives in dread of being dishonored, Pleberio does not question her response because it is a hot summer night. Lorca exploits this motif in his three tragedies. In La casa, just before the tragedy unfolds, Poncia finds Adela in the living room and asks why she is awake. Adela responds: "Voy a beber agua (bebe en un vaso de la mesa)" (262). Poncia is not fooled, but she is also not invested enough to press Adela for the truth. Adela adds: "Me despertó la sed" (262). Adela's thirst may be real, but it is her thirst for Pepe that has kept her awake all night. As Martirio points out just after this brief scene with Poncia (“¡Estaba con él! ¡Mira esas enaguas llenas de paja de trigo!” 
275), Adela has just had intercourse with Pepe, a description that helps situate the reader chronologically and appreciate the synchronism with Calisto and Melibea's last encounter. In both works, the darkness of the night, which foreshadows tragedy, is underlined. When Melibea awaits Calisto's arrival the last day, she describes the night as very dark: "Mira sus quietas sombras, quán escuras están, y aparejadas para encobrir nuestro deleyte" (582). She reiterates this while revealing to her father the reason for her impending death: "Como las paredes eran altas, la noche escura..." (600). In La casa, similarly, Lorca makes Amelia comment on the darkness of night: "¡Qué noche más oscura!" Adela complements the statement: "No se ve a dos pasos de distancia" and with her usual malice, Martirio ends: "Una buena noche para ladrones, para el que necesite escondrijo" (252). Martirio's perverse remark echoes Melibea's assertion that darkness is fitting to conceal improper behavior from inquisitive eyes.

There are other elements in Lorca's tragedy redolent of Celestina. Act III opens with a banquet of sorts in Bernarda's house that evokes the banquet at Celestina's house in act IX. During this meal, Bernarda asks Prudencia about her husband. Prudencia responds that ever since he engaged in a struggle with his siblings for the inheritance, "pone una escalera y salta las tapias del corral" (242). The reader could interpret these words as hyperbole or figure of speech, but the sentence has clear undertones of Celestina. The conflation of three symbols, namely ladder, wall, and corral, along with the act of climbing, is a thinly veiled reference to Calisto-and perhaps to Pepe himself who also climbs over the corral's walls to be with Adela. In Celestina, Calisto is semantically defined as one who incarnates such activity. During her outburst of anger in act IV, Melibea refers to him as "saltaparedes" (330). The same night of his death, Calisto commands Sosia and Tristán to carry the ladder to climb the wall ("llevarán escalas" 509). After sexual intercourse, in a rather tragicomic way, Calisto precipitously attempts to exit the garden, clambers the ladder, misses a step, and dies. As F. M. Weinberg explains, "the fortress, the garden wall, and the locked door, stand for Melibea's personal integrity, her honor, her class, her body as an illusory paradise" $(1971,138)$. Weinberg's observation is consistent with Peter Stallybrass's theory of the enclosed female body as a symbol of the hortus conclusus. The act of trespassing this enclosed fortress, therefore, represents a metaphorical penetration of the maiden's body. Bernarda recognizes this symbolism, prompting her to seal her house not only with "muros gruesos" (139), but also (figuratively) shut doors and windows airtight with bricks and mortar (157). The heavily fortified walls give Bernarda the certainty that Poncia's foreseen "cosa muy grande" (Bernarda's quotation marks) would never "traspasaría las paredes" (230).

During the same banquet, the caballo garañón disrupts Bernarda and Prudencia's conversation twice with loud kicks on the wall. The horse, which is aroused by Bernarda's new mares ("potras"), is an unsubtle symbol of Pepe, and the potras represent Bernarda’s daughters. In Celestina, Pármeno himself compares Calisto's horse, whose neighs betray his sexual arousal, with his master: "Rehincháys, don cavallo? ¿No basta un celoso en casa? ¿O barruntas a Melibea?” (292). Pármeno peppers his rhetorical questions with sexual innuendo and titillating images-if not discourses of outright bestiality. Both horses represent the unbridled lust that controls not only Calisto and Pepe, but Melibea and Adela as well. 
I want to conclude by offering a host of expressions that further showcases the influence. Bernarda's infamous cry for a speedy execution noted above (“ $i$ Matadla! ¡Matadla!”) mirrors Pármeno’s “¡muera, muera!” (499) exhortation while Sempronio stabs Celestina to death. Pármeno and Bernarda sic others on defenseless victims who are being murdered. When Celestina brings news of her first encounter with Melibea in act VI, Pármeno says in an aside: "Su lengua le querría prestar para que fablasse presto" (350). Lorca recasts this sentence by making Adela chastise Martirio: "Si quieres te daré mis ojos, [...] y mis espaldas, para que te compongas la joroba que tienes" (202). Both instances convey an act of giving a body part, followed by the prepositional phrase "para que" which introduces the purpose of said gift. Soledad Puértolas's rendition of Melibea's utterance into contemporary Spanish is closer to Lorca's redeployment: "Le daría a la vieja su lengua para que con ella hablara enseguida" (2018, 128), which is probably how Lorca interpreted Pármeno's sly comment. Just after Calisto's death, Melibea reveals her extreme pain, asserting that if she is unable to see his body, "hundiré con alaridos la casa de mi padre" (588). Lorca renews this tragic, yet beautiful, expression in Poncia's words to describe Martirio's wickedness: "Ve que el Romano no es para ella y hundiría el mundo si estuviera en su mano" (261). In Celestina, Melibea wants to drown the house and in La casa, the entire world. The most salient feature in Melibea's and Adela's characterizations is their inability to repress their desire due to their acute states of self-alienation. In Melibea's last soliloquy, she accepts that her own fate is no longer in her power: "Pero no es más en mi mano" (596). Adela expresses a similar sense of helplessness regarding her passion: "Yo no quería. He ido como arrastrada por una maroma" (238). Melibea and Adela have handed themselves over, placing their entire self-worth and affective capital in their lovers. Once their investment is lost, life loses all its value. Melibea voices this idea in economic jargon, referring to Calisto as "mi bien todo" (589).

In conclusion, Rojas's influence on Lorca permeates the entire play. It extends to nearly every aspect of the drama, from structure and characterization to imagery, style, and discourse. We may borrow Snow's forewarning regarding Celestina's influence on Cervantes $(2008,81)$ to assert that the Lorquian borrowings ought not to be considered artless imitation, let alone an act of plagiarism. Lorca absorbs, renews, and repurposes the aesthetic material in order to create a new reality, one designed to engage the modern (and postmodern) reader. Rojas himself borrowed motifs, images, and even complete sentences from San Pedro's Cárcel de amor, Alfonso Martínez de Toledo's Corbacho, Juan Ruiz's Libro de buen amor as well as from Petrarch, Seneca, and others. Lorca, just as Rojas did with his own subtexts, seamlessly interweaves his literary loans into the dramatic fabric of the play, sometimes to enhance the realism of the plot and at others to embellish the aesthetic expression. The borrowings are so perfectly knitted into the new context that one can only perceive the seams by looking intently through a loupe. In some ways, $L a$ casa represents a microcosm of the social institutions and cultural dynamics that govern Celestina's universe and, by extension, Rojas's society. La casa, like Celestina, contains characters from the most representative walks of life: The bourgeoisie (Bernarda, Pepe), servants (Criada, Poncia), prostitutes (Paca la Roseta, Poncia's mother), field workers, and a go-between/procuress of sorts (Poncia), and binding 
all of them, a repressive patriarchal system that places the value of a good name above life itself. In light of these findings, we may conclude that, at least to some degree, La casa represents a twentieth-century renewal of Celestina. Indeed, Adela is a modern version of Melibea, one who follows Melibea in rejecting everything that prevents her from enjoying the fruits of her desire. After believing that Pepe has died, she kills herself as the ultimate act of defiance toward her mother and as a way to reunite with her "dead" lover, adopting Melibea's parting words: "Su muerte combida a la mía" (600). The sixty-year-old parents, Pleberio and Bernarda, also represent mirror images. Pleberio's valedictory phrase "hac lachrimarum valle," a sound-proofed valley where only weeping can be heard, is rendered literal in Lorca's narrative. Adela's suicide turns the house into a vale of tears where the grieving sobs reverberate throughout the town, tears of pain that Bernarda, after announcing that they will drown in a sea of mourning, attempts to stifle by demanding "iSilencio!"

Open Access This article is licensed under a Creative Commons Attribution 4.0 International License, which permits use, sharing, adaptation, distribution and reproduction in any medium or format, as long as you give appropriate credit to the original author(s) and the source, provide a link to the Creative Commons licence, and indicate if changes were made. The images or other third party material in this article are included in the article's Creative Commons licence, unless indicated otherwise in a credit line to the material. If material is not included in the article's Creative Commons licence and your intended use is not permitted by statutory regulation or exceeds the permitted use, you will need to obtain permission directly from the copyright holder. To view a copy of this licence, visit http://creativecommons.org/licen ses/by/4.0/.

\section{References}

Aguilar Piñal, F. (1986). La honra en el teatro de García Lorca. Revista de Literatura, 48(96), 447-454.

Anderson, A. A. (1985). Some Shakespearian reminiscences in García Lorca's drama. Comparative Literature Studies, 22(2), 187-210.

Bugliani, A. (2001). Pharisaism: The biblical subtext in La casa de Bernarda Alba. Revista Hispánica Moderna, 54(4), 80-87.

Caro Baroja, J. (1964). Honor y vergüenza. (Examen histórico de varios conflictos populares). Revista de Dialectología y Tradiciones Populares, 20(4), 410-460.

Castells, R. (1992). Bakhtin's grotesque realism and the thematic unity of Celestina, act I. Hispanófila, 106, 9-20.

Cummins, J. G. (Ed.). (1990). Juan de Mena. Laberinto de Fortuna. Madrid: Cátedra.

de Paepe, C., \& García, M. F.-M. (2008). Catálogo general de los fondos documentales de la Fundación Federico García Lorca (Vol. 8). Madrid: Fundación Federico García Lorca.

de San Pedro, D. (1971). Cárcel de amor. In K. Whinnom (Ed.), Obras completas, II. Madrid: Castalia.

del Río, Á. (1972). Poeta en Nueva York: Pasados veinticinco años (pp. 251-293). Gredos: Estudios sobre literatura contemporánea española. Madrid.

Fernández Cifuentes, L. (1986). García Lorca en el teatro: La norma y la diferencia. Zaragoza: Universidad de Zaragoza.

García Lorca, F. (1993). Yerma. Three plays. Blood wedding, Yerma, The house of Bernarda Alba (Michael Dewell and Carmen Zapata, Trans.). New York: FSG Classics.

García Lorca, F. (1995). In A. Josephs, \& J. Caballero (Eds.), Bodas de sangre. Madrid: Cátedra.

García Lorca, F. (2011). La casa de Bernarda Alba. In M. Francisca (Ed.), Vilches de Frutos. Madrid: Cátedra.

Hart, S. M. (1989). The bear and the dawn: Versions of La casa de Bernarda Alba. Neophilologus, 73, 62-68. 
Klein, D. A. (1991). Blood wedding, Yerma, and the House of Bernarda Alba: García Lorca's tragic trilogy. Boston: Twayne Publishers.

Mancha, M. V. (2019). Melibea y Adela: Una reescritura lorquiana de la rebeldía femenina ante la violencia simbólica patriarcal. Boletín Gec, 24, 96-111.

Martínez, M. A. (1970). Realidad y símbolo en La casa de Bernarda Alba. Revista de Estudios Hispánicos, 4(1), 55-66.

Morris, B. C. (1986). The 'austere abode': Lorca's La casa de Bernarda Alba. Anales de la Literatura Española Contemporánea, 11(1), 129-141.

Puértolas, S. (2018). La Celestina. Madrid: Odres Nuevos.

Richards, K. C. (1983). Social criticism in Lorca's tragedies. Revista de Estudios Hispánicos, 17(2), 213-226.

Rodríguez Puértolas, J. (2007). La Celestina o la negación de la negación. Verba Hispánica, 15, 17-34.

Rubio, I. (1980). Notas sobre el realismo de La casa de Bernarda Alba, de García Lorca. Revista Canadiense de Estudios Hispánicos, 4(2), 169-182.

Russell, P. E. (Ed.). (2001). Fernando de Rojas. La Celestina: comedia o tragicomedia de Calisto y Melibea. Madrid: Castalia.

Sears, T. A. (1992). Love and the lure of chaos: Difference and disorder in Celestina. Romanic Review, 83(1), 94-106.

Sharp, T. (1961). The mechanics of Lorca's drama in La casa de Bernarda Alba. Hispania, 44(2), 230-233.

Snow, J. T. (2008). Notes on Cervantes as a reader/renewer of Celestina. Comparative Literature, 60(1), 81-95.

Swietlicki, C. (1985). Rojas' view of women: A realanysis of La Celestina. Hispanófila, 85, 1-13.

Weinberg, F. M. (1971). Aspects of symbolism in La Celestina. MLN, 86(2), 136-153.

Publisher's Note Springer Nature remains neutral with regard to jurisdictional claims in published maps and institutional affiliations. 